\title{
The structural method of modular system expressed in contemporary fashion design
}

\author{
Jeong-A Yoon* and Younhee Lee ${ }^{\dagger}$ \\ Dept. of Clothing \& Textiles, Seowon University, Korea* \\ Dept. of Clothing \& Textiles, Hanyang University, Korea \\ 현대 패션디자인에 표현된 모듈러 시스템의 구조방식 \\ 윤 정 아* ${ }^{*}$ 이 연 희 ${ }^{\dagger}$ \\ 서원대학교 의류학과*, 한양대학교 의류학과
}

\begin{abstract}
This study attempted to figure out the usage of the modular system in other fields through literature review and empirical study, analyze its structural method in fashion. After analyzing architecture \& product-related books, the Internet data and previous studies, the modular system's five structural methods were obtained. Then, 991 photos of women's clothes from 2003 to 2014 were collected through the fashion websites in Korea and abroad. The results can be summarized as follows: First, the following five structures were derived: assembling structure, overlapping structure, arrangement structure, inserting structure and folding structure. Second, according to analysis on the structural method of the modular system in modern fashion, overlapping structure (34\%) was the most common. Third, in fashion, the use of fastener for installation and removal is important for assembling structure. In terms of overlapping structure, 3D volume by vertical accumulation was commonly observed. Arrangement structure revealed a horizontal and flat shape through simple arrangement. In inserting structure, on the contrary, non-standardized modules were used as a part of clothes or decorative elements. In folding structure, origami technique for reduction and expansion was used.
\end{abstract}

Keywords: modular system(모듈러 시스템), assembling structure(조립구조), overlapping structure(중첩구조), arrangement structure(배열구조), inserting structure(삽입구조), folding structure(접이구조)

\section{Introduction}

건축에서 출발한 치수 개념인 모듈러 시스템은 산업이 발달함에 따라 새롭고 다양한 디자인을 만
들어낼 수 있는 표현 방식으로 그 의미가 확대되고 있다. 조합되어 완성된 형태를 통해서 기능의 확장, 호환성, 사용자의 다양한 욕구에 맞추어 활용도가 증가하고 있기 때문이다. 원래 모듈러 시스템은 단 순화, 규격화를 통해 대량 생산을 용이하게 하기

Received 18 August 2014, revised 30 September 2014, accepted 6 October 2014.

${ }^{\dagger}$ Corresponding author (yiyhee@hanyang.ac.kr)

This is an Open Access article distributed under the terms of the Creative Commons Attribution Non-Commercial License (http://creativecommons.org/licenses/by-nc/3.0) which permits unrestricted non-commercial use, distribution, and reproduction in any medium, provided the original work is properly cited. 
위해 시작되었지만, 오히려 현대 사회에서는 대량 생산으로는 충족시킬 수 없는 다양한 소비자의 요 구를 수용하기 위해 활용되고 있다. 구성 요소간의 상관관계에 따르는 문제를 해결하는 코디네이터라 는 개념으로 모듈을 적용하여 제품이나 의복에서 의 소형화, 경량화가 가능하기 때문이다. 모듈러 시 스템은 활용 영역에 따라서 이해 범위와 활용도가 확대되어 다양한 방법과 디자인으로 제시되고 있 다. 모듈러 시스템에 나타나는 조합의 방법은 단순 하게 몇 가지의 방식으로는 단정 지을 수 없다 (Park, 2008). 그것은 모듈의 응용을 통한 디자인의 확대 작업이며, 조형적 구성과 일정하게 정해진 형 식에 따라 다양한 표현 방법을 무한하게 이끌어낼 수 있다.

모듈의 개념이 대두된 것은 건축 분야이며, 모듈 러 시스템의 활발한 적용도 주로 건축과 제품에서 많이 활용되고 있다. 그러나 모듈러 시스템과 연관 된 선행 연구는 대부분이 가변성, 가변형 또는 가 변 시스템의 일부분으로만 국한시켜 논의되고 있 었으며, 특히 모듈러 시스템에 관한 패션 디자인 연구는 타 영역에 비해 매우 미미한 것으로 나타났 다. 패션 디자인에 모듈러 시스템을 적용하고 활용 하기 위해서는 본질적인 구조의 재해석이 필요하 며, 기본 모듈의 근본적인 차별화와 조합의 의미 또한 다양한 표현이 가능하게 할 수 있는 유연한 표현 방법의 개발이 요구된다.

이에 본 연구는 모듈러 시스템에 관한 문헌 연구 와 건축·제품에서의 사례 조사를 통한 실증적 연 구를 수행하여 타 영역에서의 활용 방안을 알아보 고, 모듈러 시스템의 구조 방식의 분석 기준을 마 련하였다. 이를 적용하여 패션 디자인에서 나타난 모듈러 시스템의 구조 방식을 고찰하는데 목적이 있다.

\section{Background}

\section{Modular system}

\section{1) Conception}

원래 '모듈(module)'이라는 말은 그리스의 고대 건축물들과 신전의 기둥에서 하부 굵기를 1 Module
로 설정하고, 다른 부분을 이 길이와 비례하게 디 자인하는 데에서 모듈의 개념이 비롯되었다고 볼 수 있다(Kwon, 2002). 여기에서 한걸음 더 나아가 르 꼬르뷔지에(Le Courbusier)에 의해 '황금 분할(section d'or)'의 관념과 결부하여 새롭게 해석한 것이 '모듈 러(Modulor)'라고 할 수 있다. '모듈러(Modular)' 개 념은 건축에서 출발하였지만, 이후 다양한 분야의 디자인에 응용되었다는 점에서 의미가 있다고 할 수 있다.

모듈에 대한 정의는 다양하다. MIT 슬론 스쿨(MIT Sloan School of Management) Fixon(2007) 교수는 제품 모듈을 주제로 삼고 있는 공학 및 경연 분야 의 논문을 광범위하게 조사한 바 있는데, 이 조사 결과에서 학자의 관점에 따라 모듈 개념이 다양하 게 사용되고 있음을 밝힌 바 있다(Jeong 재인용, 2008). 시스템은 전체의 의미로 특정한 기능을 갖기 위해 여러 가지 하위 기능들을 통합화하는 것을 말하며, 시스템을 구성하여 조직하는 과정에서 모듈을 사 용하여 시스템의 상호 관련성에 따르는 여러 가지 문제점들을 해결하는 것을 '모듈러 시스템'이라고 한다(Ahn, 2005). 모듈을 의미하는 기준 치수와 모 듈러 척도를 사용하여 건축 전반에 계획의 용이성, 시공의 용이성, 경제성을 부여하면서 미적인 질서를 이루려는 것을 건축에서는 '모듈러 시스템(Modular System)', '모듈러 코디네이션(Modular Coordination)', '모듈러 에셈블리(Modular Assembly System)', '모 듈러 건축(Modular Construction)', '모듈러 하우징 (Modular Housing)' 등의 용어들로 혼용하여 사용 하고 있었다. 모듈화 제품 구조 영역에서는 주로 '모 듈화(Modularlity)'라는 용어가 모듈러 시스템의 개 념으로 통용되고 있었으며, Lee(2007)는 ‘모듈화’란 독립적으로 설계가 가능하며, 하나로 합치더라도 전체로서 제 기능을 할 수 있는 그런 작은 하위 시 스템들을 개발한 뒤, 이를 적절히 조합하여 완제품 이나 프로세스를 구축하는 방식을 의미한다.'고 하 였다. 따라서 모듈러 시스템의 활용을 통해 조합과 분리를 통한 다양한 기능을 창출하고, 변환을 통해 환경 변화에 능동적 대처를 할 수 있으며, 용도에 따른 부품 교체화와 소비자의 다양한 기호를 충족 시킬 수 있다(Go, 2006). 각 분야에서 사용하고 있 는 용어와 정의는 다양하지만, 이를 종합해 보면 
모듈러 시스템은 2 개 이상의 모듈이 다양한 조합을 통해 구성되는 형태로서, 각 부분들이 구조성을 가 지고 상호 작용을 통해 나머지 부분에 영향을 주지 않고, 재구성될 수 있는 집합이라고 할 수 있다.

\section{2) Advanced research analysis}

모듈러 시스템에 관한 논의는 앞서 언급한 바와 같이 분야마다 다루는 의미와 용어의 차이가 존재 한다. 건축에서 모듈러 시스템이라는 주제로 연구 되고 있는 내용들은 가변적 건축의 다양한 방법들 중 하나로 볼 수 있는 모듈 방식으로 국한되어 있 었다. 모듈러 시스템은 실질적으로 건축 분야에서 는 모듈방식 자체를 '모둘러 시스템'이라 칭하며, ‘모듈러 어셈블리'나 ‘모듈러 코디네이션'이라고도 하는 유닛의 결합 구성 방식에 관하여 논의되고 있 는 것으로 조사되었다. 또한, 건축에서의 모듈러 시 스템에 관한 연구는 제품과 패션에 비해 양적으로 는 많지만, 분류 기준을 제시하고 있는 연구가 매우 미비한 것으로 조사되었다. Yoon(2006)과 Kim(2012) 은 모듈러건축을 분류하고 특성에 관한 연구를 진 행하였으나, 디자인의 측면에서보다는 시공을 위한 모듈의 형태적인 분류 측면에서 이루어졌으며, 구 조용 모듈과 유닛 형태의 구조로 나누고, 구조용 모듈은 코너 지지형과 내력 벽체형으로 분류하며, 유닛형태의 모듈을 닫힌 유닛, 열린 유닛 그리고 설비유닛으로 분류하였다.

제품에 있어서의 모듈 구조의 각각의 방식은 기 능 요소와 인터페이스 방식의 정의에 따라 달라진 다. Bae(2005)는 이들 방식의 차이를 모듈들간의 상호작용 및 유기적 관계에 따라 슬롯(slot), 버스 (bus), 섹셔널(sectional) 세 가지 방식으로 구분하였 으며, $\mathrm{Go}(2006)$ 은 제품, 서비스의 여섯 가지 모듈화 유형을 Ulrich and Tung(1991)의 이론에 의해 구성 요소 공유형 모듈화(Component-Sharing Modularity), 구성 요소 교환형 모듈화(Component-Swapping Modularity), 맞춤형 모듈화(Cut-To-Fit Modularity), 혼 합형 모듈화(Mix Modularity), 버스형 모듈화(Bus Modularity), 조립형 모듈화(Sectional Modularity)로 나누었다.

모듈러 시스템에 관한 패션 디자인 연구는 타 영 역에 비해 연구사례가 더욱 부족한 실정이다. Yang
(2008)과 Son(2012)은 건축의 모듈러 시스템과 패 션에서의 모듈러 시스템을 비교해서 설명하였는데, Yang(2008)의 연구에서는 패션과 건축에서의 모듈 러 시스템만을 다루었으며, 패션의 모듈러 시스템 을 폴딩 방식과 모듈 방식으로 크게 나누고, 이중 에서 모듈 방식을 다시 레이어링 시스템, 컴바인 시스템, 레고 시스템으로 세분화하였다. Son(2012) 은 패션에서의 모듈러 시스템을 폴딩 시스템, 레이 어링 시스템, 컴바인 시스템, 컨테이닝 시스템으로 구분하여 살펴보고 작품을 제작하였지만, 공기주입 형 다기능 재킷에만 국한하여 연구하였다. 모듈러 시스템을 분석하는 데에 있어서 $\operatorname{Kim}(2006)$ 은 세 가 지 브랜드를 통해서만, Yang(2008)은 세 명의 디자 이너를 통해서만 진행하였기 때문에 패션 전반에 서 나타나는 모듈러 시스템의 구조방식을 파악하 기에는 한계가 있었다.

\section{Modular system in architecture}

건축에서의 모듈러 시스템은 공기 단축, 건축물 의 이동 및 재사용, 공사비 절감을 목적으로 공장 에서 생산한 건축 모듈을 현장에서 조립하는 건축 시스템이며, 시공 공법으로 건축의 복잡한 과정을 공장 제작으로 표준화 효율화 시키는 동시에, 현장 작업을 최소화 하는 친환경 건축 시스템이다(Jee, 2012). 모듈의 실제 적용이 가능한 체계는 구조 시 스템에 의해서 발견되는 구조 모듈(Structural Module) 과 내부의 실생활에서 발견되는 공간 모듈(Space Module) 등 두 가지로 분류된다(Lee \& Kim, 2000). 건축 모듈들의 활용 방식은 크게 수직 방향의 모듈 러 시스템과 수평 방향의 모듈러 시스템으로 나누 어 살펴볼 수 있다.

고정적인 수직 조합은 아파트의 구조와 같이 동 일한 유닛이 쌓여 올라가는 형태를 예로 들 수 있 다. 이러한 수직 축적 방식은 건축물이 밀집된 도 시에서 효율적인 공간을 창출하는 대표적 구성 방 식이다. 일본 메타볼리즘(Metabolism)의 건축가 키 쇼 쿠로카와(Kisho Kurokawa)가 설계한 나가긴 캡 슐 타워(Nakagin Capsule Tower)는 두 개의 타워에 나선형 형태로 캡슐이 부착되어 공장에서 조립식으 로 유닛을 제작하여 기중기로 하나씩 들어 올린 후 타워에 플러그 인(Plug-in)시켜 완성하였다(Fig. 1a). 
그렉 린(Greg Lynn)에 의해 만들어진, Blobwall 가설건물은 벽돌과 같은 전통적인 건축 자재 대신 독립적으로 실내와 실외의 벽에 사용 가능한 시스 템이다(Fig. 1b). 각각의 모듈은 저밀도의 재활용이 가능하며, 충격에 강한 폴리머(polymer)를 자동 기 계 장치로 재단하여 만든다. 모듈들은 수평 방향으 로 반복적으로 결합되어 원하는 모양으로 변형이 가능하고, 결합 정도에 따라 공간의 확장이 이루어 진다. 전통적인 건축의 가장 기본적인 구성단위인 벽돌을 새로운 소재의 컬러풀한 플라스틱으로 만 들어진 경량체 모듈형 요소로 전환하여 혁신적이 고 다양한 재해석을 시도했다.

움직임을 통해 변화를 가능하게 하는 건축에서 의 모듈러 시스템은 건축물 전체의 움직임이나 변 화보다는 용도에 따라 부분적으로 이용되는 동적 시스템인 경우가 더 많다(Yang, 2008). 반 시게루 (Ban Shigeru)가 2000년에 설계한 컨테이너 주택 형태인 네이키드 하우스(Naked House)는 내부 공 간에 4 개의 움직이는 박스를 삽입하여 넓은 공간을 필요에 따라 나누거나 통합하여 활용이 가능하도 록 만든 모듈러 시스템 건축이다(Fig. 1c).

모듈형 건축물은 사용자가 어떤 장소로든 거주 지를 옮겨도 최소한의 노력으로 다시 설치할 수 있 다는 장점이 있다. 디자이너 알베르토 라라(Alberto Lara)와 폴라 노게론(Paula Nogueron)가 구상한 태 양열 조립식 모듈 기반으로 재활용이 가능한 주거 단위인 $\mathrm{ADEX}$ 는 자급 자족 형태의 친환경 요인을 갖고 있는 건축이다(Fig. 1d). 이 주거 단위는 이동
생활을 위해 자체적으로 그리고 주거 공간을 둘러 싸고 있는 천연 자원을 통해 영양을 공급받는 자급 자족력을 갖는 모듈러 시스템으로 시공되었다. 각 각의 삼각형 모듈은 독립형 장치를 유지하기 위한 에너지 시스템을 갖추고 있고, 광전지를 사용하여 태양 에너지를 수집하여 전기를 제공한다. 거주자 에 의해 발생하는 폐기물들은 재활용될 수 있는 천 연 가스와 천연 비료를 만드는데 사용된다.

몰로디자인(Molodesign)이 2003년 개발한 'softwall, soft Blocks modular system'은 광활한 지역에서 더 친밀한 공간을 형성하기 위해 자유롭게 확장과 수 축을 할 수 있는 유연한 접이식 독립형 파티션 시 스템이다. 연질 반투명 또는 불투명 버전은 공간의 빛을 조각하는 동시에 'softwall+softblock'의 성글 게 짜인 구조는 소리를 꺾는 역할을 한다(Fig. 1e). 재활용 섬유로 만들어진 크래프트(Kraft paper)는 뺏 뻣하고 강력한 표백 종이로써 방화 효과가 있다. 주름 구조로 인해 유연한 변형이 가능한 이 벽체 시스템은 가변형 건축의 실내 구성요소로 활용이 가능하며, 모듈화 되어 있어 높이나 형태의 변형과 위치 이동이 자유롭다. 건축에서 나타난 모듈러 시 스템의 사례들에서 나타난 특징들을 바탕으로 분 류하여 정리한 구조방식은 〈Fig. 1〉과 같다.

\section{Modular system in product}

기계나 시스템의 구성 요소들이 독립적으로 분 해 가능하고, 그 기능성을 상실하지 않으면서 다양 하고 새로운 구성으로 재결합될 수 있을 때 높은
Vertical accumulation: Horizontal accumulation: Overlapping structure Arrangement structure

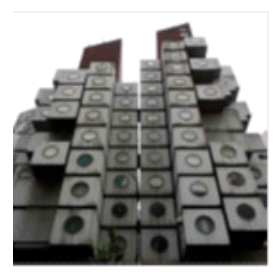

〈Fig. 1a〉 Nakagin Capsule Tower, 1971. From http://www. businessinsider.com

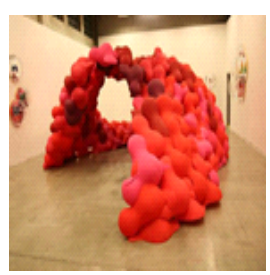

〈Fig. 1b〉 BLOBWAL: 〈Fig. 1c〉 Naked modular building system. From http:// www.ecofriend.com
Inserting structure

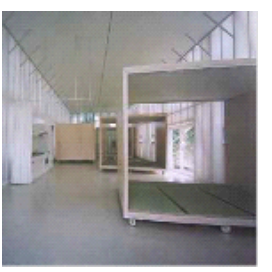

House, Ban Shigeru, 2000. From http:// detail-online.com
Movement structure

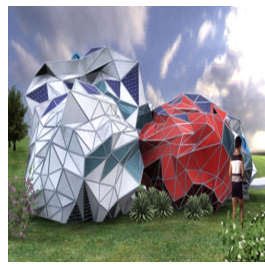

$\langle$ Fig. 1d〉 ADEX,

Alberto Lara \& Paula Nogueron. From http:// www.ecofriend.com
Folding structure

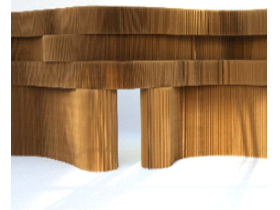

〈Fig. 1e〉 Softwall, soft Blocks modular system, 2003. From http:// molodesign.com

〈Fig. 1〉 Structural method for case analysis in architecture design 
정도의 모듈화를 가지고 있다고 할 수 있다(Sanchez, 1995). 구성 요소들이 이질적일수록 시스템의 모듈 화는 증대된다. 구체적으로 시장에서 이용 가능한 기술적인 옵션들의 다양성이 크거나, 구성 요소의 차별화가 클수록 모듈화 시스템은 더 큰 장점을 지 니게 된다(Jacobides, 1997). 모듈러 시스템의 디자 인들은 어느 한 가지의 모듈화 방식만을 고집하는 것이 아니라, 두 가지 이상의 모듈화 방식이 혼재 되어 있는 경우가 대부분이다. 그 중에서도 조립구 조는 모든 모듈러 시스템의 구조방식 가운데 가장 폭넓은 수준의 다양성과 선택 요소를 제공한다(Kim, 2011). 조립구조의 모듈화는 여러 구성 요소가 표 준적인 접촉면을 통해 서로 연결될 수만 있다면 그 수가 몇이든 형태가 어떻든 구성 요소를 임의의 방 식으로 배열할 수 있다. 모듈러 시스템의 조립구조 는 상품의 구조 자체를 다양하게 바꿀 수 있기 때 문에 다양성의 특면에서 무한한 가능성을 지니고 있다고 볼 수 있지만, 반면에 실행하기가 가장 어 렵다는 문제점이 있다.

맥포머스(Magformers)는 수학 도형을 기반으로 구 성된 교구로, 단순한 기하학적 도형을 기본으로 하 는 피스(piece)들로 구성되어 있다. 대표적인 조립 형 모듈화 제품인 레고 블록처럼 피스를 끼워서 조 립하고 쌓기만 하는 것이 아니라, 도형 내부에 있 는 네오디뮴(neodymium) 마그넷을 사용한 자성체 가 회전 현상을 일으켜, 극에 상관없이 도형의 모든 부분이 서로 붙이는 방식이기 때문에, 평면에서 입 체로 어느 방향이든 360 도 연결이 가능하다(Fig. 2a).

$\mathrm{MIO}$ 사의 모듈형 파티션은 다양한 컬러로 구성 된 동일한 판지 형태의 유닛들은 각각의 유닛에 있 는 틈새에 끼우거나 빼는 방법으로 목적에 따라 조 립과 분해를 할 수 있다(Fig. 2b). 재활용된 이중 판 지 형태의 모듈 구성 시스템은 기존 구조를 손상시 키지 않으며, 별도의 도구 없이 독립형, 조각 형태 의 스크린, 임시 파티션으로 바꿀 수 있다. 사용자 의 필요에 따라 자유로운 축적이 가능한 모듈형 제 품이다. 또한 도구나 장비 없이 모듈들을 반복적으 로 결합하고 축적하여 확장시켜 룸이나 디스플레 이 공간을 만들 수도 있다.

마이클 알비스(Michael Alvisse)는 상호작용할 수 있는 퍼즐형 변형 가구 형태로 배열구조의 모듈러 가
구를 디자인했다(Fig. 2c). 퍼즐 모듈은 하나의 모듈 자체만으로도 의자나 테이블로서의 독립적인 기능 을 수행할 수 있을 뿐만 아니라, 모듈들의 조합에 따 라 대형 가구로서의 기능까지 가능하며 놓는 위치 나 각도에 따라 형태의 다양한 변형이 이루어지는 배열 구조이다. 자연 친화적인 재료를 사용한 모듈 요소들은 소파, 의자, 테이블, 침대, 또는 단순히 부 드러운 조각 등의 역할로 배치하는 것이 가능하다.

표준적인 제품, 서비스가 변화할 수 있는 구조를 가지고 있는 삽입 교환구조는 다른 모든 것을 표준 구조에 연결할 수 있는 구성 요소로 모듈화하는 것 이 중요하다. 예를 들어, BMW Design works USA 와 Thermaltake사가 합작으로 디자인한 PC 케이스 의 시제품인 'Level 10 '은 컴퓨터의 개별 컴포넌트 를 베이스에 부착하는 방식으로 개별 구획하여 설 치할 수 있다(Fig. 2d). 각 PC의 구성 요소들이 각각 자신의 모듈화된 인클로저(enclosure)를 갖고 있는 데, 강력한 수직 방열판과 수평적으로 이어진 개별 구성 요소의 비대칭 배열은 강한 건축적인 이미지 를 보여준다. $\mathrm{PC}$ 의 구성 요소들은 본체에서 분리되 어도 각각 개별적으로 활용 가능하고 어떤 본체에 삽입과 교환되느냐에 따라 변화된다.

제품 디자인의 매스 커스터마이제이션(Mass Customization)은 가변성을 상품의 디자인에 통합시키는 것이다. 대부분의 벽지들이 $2 \mathrm{D}$ 를 고수하는 반면에, $\mathrm{Mio}$ 사의 서로 다른 패턴과 컬러를 가지는 벽체 패 널들은 새로운 초경량 소재를 사용하였기 때문에 $3 \mathrm{D}$ 구조를 갖는다. 여러 개의 타일들은 모듈화되어 어떤 반복 패턴으로 붙이는가에 따라 입체적인 패 턴으로 공간을 더욱 창조적으로 꾸밀 수 있게 하며, 사용자가 타일을 주문 제작하거나 부착된 타일의 방향을 자유롭게 바꿀 수 있도록 함으로써 더 다양 한 패턴과 디자인의 믹스 앤 매치가 가능하도록 해 준다(Fig. 2e).

보아스 멘델(Boaz Mendel)의 루프 의자(Loop Chair) 는 하나의 아이템 가격에 12 가지 형태와 기능을 제 공하는 모듈형 디자인이다(Fig. 2f). 7 개의 모듈로 구성된 루프 의자는 접이 구조방식이 갖는 유연성 으로 인해 다양한 크기와 모양으로 변형될 수 있어 서 의자나 책장, 테이블 등의 여러 가지 기능을 제 공한다. 서로 다른 길이로 구성된 7개의 모듈형 보 


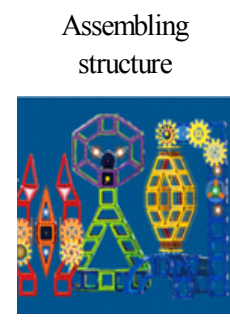

〈Fig. 2a〉 Magformers. From http://www.magfor mers.co.kr

\section{Accumulation structure}

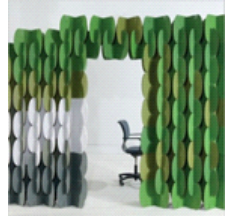

〈Fig. 2b〉 MIONomad Modular Partitions. From http://mioculture. com

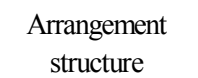

Inserting switching structure



〈Fig. 2c〉 Puzzling Transformer Furniture. From http://www.trend hunter.com

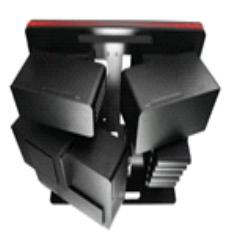

$\langle$ Fig. 2d〉 Thermal Take Level 10. From http://forums. vr-zone.com
Customization structure

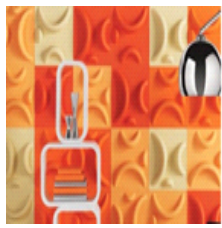

〈Fig. 2e〉 Recycle Paper, Mio. From Loop Chair. From http://mioculture. com
Folding structure

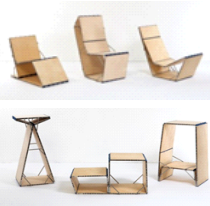

〈Fig. 2f〉 Modular http://www.green prophet.com

〈Fig. 2〉 Structural method for case analysis in product design

드는 경첩으로 연결되어 있어서 누구나 간단한 조 작을 통해 원하는 모양으로 형태를 바꿀 수 있다.

위에서 살펴본 제품디자인에서 나타난 모듈러 시 스템의 사례들에서 나타난 특징들을 바탕으로 분 류한 구조방식은 〈Fig. 2〉와 같다.

\section{Methods}

통용되는 범주 안에서, 모듈러 시스템에 관하여 혼용되고 있는 개념들을 정립할 필요가 있다고 사 료된다. 이에 본 연구자는 모듈의 개념과 모듈러 시스템에 대해서 가장 깊이 그리고 폭넓은 연구가 이루어지고 있는 건축, 제품 디자인의 분야의 선행 연구와 사례를 조사, 분석함으로써 타당성이 있는 개념 정립을 하고, 이를 패션 분야의 특성을 감안 하여 사례 분석에 적용하고자 한다. 모듈러 시스템 과 관련된 국내외 전문 서적과 건축, 제품, 패션 관 련 논문, 학술지 등의 선행 연구를 통해서 본 연구 의 주요한 범주가 되는 모듈러 시스템에 대하여 일 반적인 고찰을 하여 모듈러 시스템에 관한 일반적 인 개념과 정의에 대해 정리하였다. 선행연구를 통 한 문헌 연구와 건축과 제품의 모듈러 시스템 사례 분석을 통한 실증적 연구를 통해 공통적으로 나타 나는 유사개념과 공통점을 추출하여 구조 방식을 분류하여 패션에 나타난 사례들을 분석하기 위한 기준을 마련하였다.

선행 연구를 분석한 결과, 같은 분야 내에서는 용 어 사용에 있어 근소한 차이를 두고 비슷하게 적용
하는 면이 있었지만, 건축, 제품 그리고 패션의 분 야를 서로 비교해 보면 유사한 내용임에도 불구하 고, 사용하는 용어에는 차이가 있었다. 분야별로 용 어 표현의 차이는 분야의 전문성이 내포되어 나타 났지만, 내용적인 측면에서는 사례 분석을 통해 나 타난 구조 방식과 연관성이 있었으며, 그 관계는 〈Fig. 3〉과 같다. 패션 디자인에 적용하기 위한 분 석 기준을 도출하는 과정에서 건축에서만 보이는 이동 구조와 제품에서만 나타난 맞춤 구조는 제외 하였으며, 건축에 있어서 축적과 배열은 근본적으 로 유닛들 간의 결합을 전제로 이루어지는 구조이 므로 별도로 조립구조라는 용어로 분류한 것은 없 지만, 제품에서의 모듈러 시스템 구조와 공통점이 있는 것으로 보아 분석 기준에 포함하였다. 또한 Son(2012)의 연구에서 제시한 분류 기준을 수정 보 완하여 수직적 축적을 중첩의 의미로, 수평적 축적 을 배열의 의미로 적용하였다. 건축 분야의 경우, 모듈러 시스템을 이루는 구조 방식에 관한 분류보 다는 기본 단위가 되는 유닛의 형태와 구조만을 분 류하고 있는 것으로 나타났기 때문에, 사례 분석과 의 연결성을 고려하여 구조 방식을 도출하였다. 선 행 연구에서는 건축과 제품 모두에서 접이구조에 대한 직접적인 언급이 없었으나, 본 연구자가 사례 조사를 위해 수집한 자료들과 선행 연구에서 제시 된 사례들의 경우에는 모듈화된 유닛들의 접이구 조에 의한 표현방식들이 나타났으므로 이를 분류 기준에 추가하였다.

건축과 제품 분야 모두에서 나타나는 구조 방식 


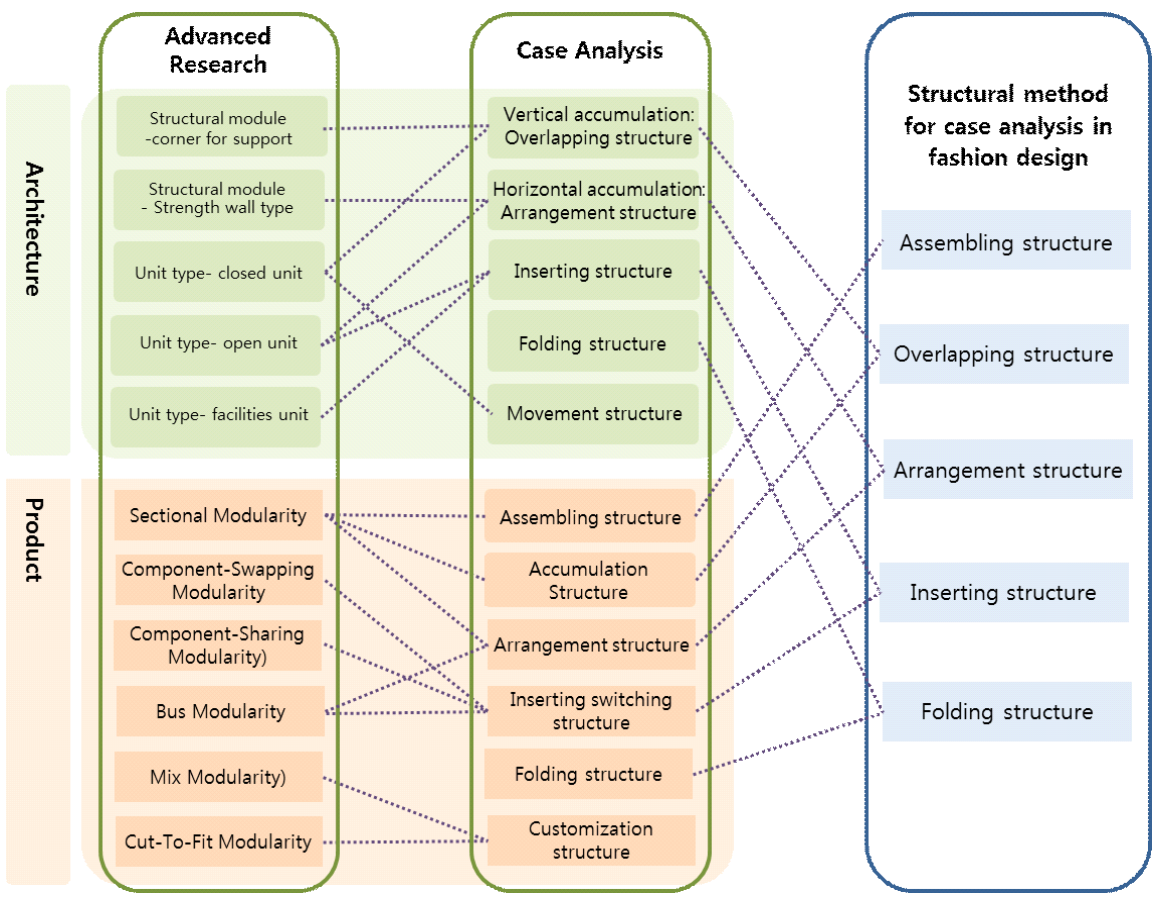

〈Fig. 3〉 Generation process of structural method for case analysis in fashion design

만을 선별하여 추출한 결과, 조립구조, 중첩구조, 배열구조, 삽입구조, 접이구조의 다섯 가지로 나타 났으며, 이들 방식을 활용하여 다음 장의 패션 디 자인에서 나타나는 모듈러 시스템의 사례를 분석 하고, 또 패션 분야에서 나타나는 구조 방식을 조 사 분석하고자 하였다. 모듈러 시스템에 관한 선행 연구에서 언급된 디자이너 7명, 건축적 디자인과 가변적 디자인의 선행 연구에서 선별된 디자이너 21 명, 신진 디자이너 22 명으로 구성된 50 명의 디자 이너의 작품들이 분석의 대상이 되었다. 패션 디자 인 분야에서 시도된 모듈러 시스템에 관한 선행 연 구의 범위 이후인 2003년 S/S부터 2014년 F/W까지 12 년간을 연구 범위로 설정하고, 국 - 내외 패션 전 문 웹 사이트를 활용하여 여성복 사진 자료를 수집
하였다. 연구자에 의해 1 차 수집된 사진 자료인 총 1,347 장에 대하여 의류학 전공 박사 7 인으로 구성 된 전문가 집단의 검증을 시행하여 최종 선별된 991장의 사례를 도출된 구조방식의 분류 기준에 따 라 분석하였다.

\section{Results and Discussion}

선행 연구와 사례 분석 통해 도출된 현대 패션에 나타난 모듈러 시스템의 구조 방식인 조립구조, 중 첩구조, 배열구조, 삽입구조, 접이구조의 분류 기준 에 의해 전문가 집단에서 선택한 991장의 사진 사 례들을 분석한 결과, 중첩구조(34\%)가 가장 많이 나 타났고, 배열구조(30.4\%), 조립구조(20.3\%), 접이구

$\langle$ Table 1〉 The appearance percentage of the structural method in fashion design

\begin{tabular}{c|c|c|c|c|c}
\hline $\begin{array}{c}\text { Structural } \\
\text { method }\end{array}$ & $\begin{array}{c}\text { Assembling } \\
\text { structure }\end{array}$ & $\begin{array}{c}\text { Overlapping } \\
\text { structure }\end{array}$ & $\begin{array}{c}\text { Arrangement } \\
\text { structure }\end{array}$ & $\begin{array}{c}\text { Inserting } \\
\text { structure }\end{array}$ & $\begin{array}{c}\text { Folding } \\
\text { structure }\end{array}$ \\
\hline Total(pcs) & 201 & 337 & 301 & 73 & 79 \\
\hline Percentage(\%) & 20.3 & 34.0 & 30.4 & 7.3 & 8.0 \\
\hline
\end{tabular}


조 $(8 \%)$, 삽입구조(7.3\%)의 순서로 나타났다(Table 1). 전체적으로 중첩구조와 배열구조가 압도적으로 많 고, 접이구조와 삽입구조의 비율은 매우 낮은 편으 로 나타났다. 이러한 결과는 디자인을 기획하고 실 물로 제작하는 과정에서 조립구조, 접이구조, 삽입 구조는 중첩구조와 배열구조에 비해 구성방법에 대한 철저한 의도와 계획이 요구되고, 제작과정 상 에서 난이도가 더 높기 때문인 것으로 추측된다.

\section{Assembling structure}

조립은 '여러 부품을 하나의 구조물로 짜 맞춤' 을 의미하여(National Institute of the Korean Language, 2014), 여러 부품이라는 것은 모듈러 시스템의 경 우 모듈을 의미한다. 모듈화된 의상은 부분이나 전 체를 탈, 부착할 수 있거나, 다른 형태로 변형할 수 있다. 조립구조는 의복 내에서의 변화뿐만 아니라, 아이템 자체의 전환을 위해 주로 쓰이는 방법이기 도 하다. 의복 구성의 일부가 아닌 전체를 분리시 키는 경우는 새로운 조합이 되고, 분리된 부분은 자체로서 아이템의 전환도 가능하다. 이것은 디자 인의 형태가 사전에 계획되고, 디자이너의 감성이 나 감각보다는 치밀한 사전 계획 하에 계산되는 형 태 구성이기 때문에 일반적인 디자인 개발이나 제 작 과정의 난이도가 높다고 할 수 있다.

건축이나 제품에서 나타나는 조립구조와는 달리 복식에서 조립과 분해는 탈, 부착 방식으로 볼 수 있으며, 이러한 탈, 부착을 위해서 주로 지퍼, 단추, 스냅 등의 패스너가 가장 많이 활용되었다. 조립이 가능한 구조는 각각의 요소들의 분리가 가능하며, 그것으로 인해 변형이 가능한 경우가 대부분이었 다. 패션에서의 모듈러 시스템 구조 방식은 일반적 으로 의복을 구성하는 몸판과 소매, 카라 등의 부 분들을 각각의 독립적인 패널로 보고, 구성요소들 의 조립과 분해를 의도한 작품이 주로 나타났다. 또는 신체를 감싸는 면적을 분할하여 모듈화하고 모듈들의 연결과 분리가 가능하도록 하였다. 분리 와 연결을 통해 길이와 실루엣의 변화, 소재와 컬 러의 변화 등이 가능하였는데, 그 중에서도 몸판 밑단이나 소매의 밑단부분과 소매 자체의 탈, 부착 이 가장 많이 나타났다.

의복의 구성요소들을 모듈화하고, 조립과 분리가
가능한 구조는 셀린느(Celline) $2003 \mathrm{~S} / \mathrm{S}$ 컬렉션과 A. F. 반데버스트(A. F. Vandevorst) $2010 \mathrm{~F} / \mathrm{W}$ 컬렉 션에서 대표적으로 볼 수 있다. 셀린느는 상의를 구성하는 몸판의 패널과 소매 등을 모두 분리 가능 하도록 제작하고, 스냅으로 탈, 부착을 할 수 있기 때문에 실루엣의 변형이 가능한 디자인을 선보였 다(Fig. 4). 예를 들어 재킷이라는 아이템 내에서 장 식적인 주머니의 탈, 부착이 가능할 뿐만 아니라, 재킷에서 소매를 분리하면 베스트로의 아이템의 전환이 이루어진다. 반데버스트는 구조적인 실루엣 의 재킷이나 코트의 모든 구성 부분을 모듈화하여 조립이 가능하도록 한 시리즈를 통해서 서로 다른 재질과 컬러의 의상이라도 서로 부분을 교체하여 조립이 가능하도록 하였다(Fig. 5). 그의 작품들의 패널들은 다른 디자이너들과 달리 메탈 볼트(metal bolt)에 의해서 조립이 가능한 구조로 이루어졌다.

신체를 감싸는 면적을 분할하여 모듈화하고 모 듈들의 연결과 분리가 가능하게 한 사례들은 돌체 앤 가바나(Dolce \& Gabana)의 2003 F/W 컬렉션과 파코 라반(Paco Rabanne)의 2004 S/S 컬렉션에서 대표적으로 나타났다. 돌체 앤 가바나는 저지 소재 를 활용하여 일정한 비율의 유사한 크기로 분할된 조각들의 모듈들이 인체에 편안하게 밀착되도록 하고, 스냅을 이용하여 모듈들을 조립하였다(Fig. 6). 파코 라반은 돌체 앤 가바나와 유사한 방식이지 만 플라스틱과 금속 소재를 이용하여 건축적인 조 형미를 추구하였고, 모듈들을 연결하는 방식은 일 반적인 패스너가 아닌 금속 링이나 체인을 이용하 였다(Fig. 7).

미카엘 헤크맷(Michael Hekmat)이 이끌고 있는 폴란드 브랜드 BLESSUS는 지퍼를 이용하여 착용 자의 취향에 맞게 수정할 수 있는 모듈형 의류를 제작하고 있다. 컨실 지퍼(conceal zipper)로 제작된 모듈형 의상은 바쁜 일상에서 하루에도 몇 가지 스 타일이 필요한 여성들을 고객으로 커스터마이제이 션되고 있다(Fig. 8). 컨실 지퍼를 활용하는 것은 캐 쥬얼 복장이 스마트한 근무복이 되거나 일상복이 되는 것을 가능하게 해주었다. 뿐만 아니라 색상의 조합이나 추가적인 의복 구성요소의 맞춤 서비스 를 제공하고 있어서 소비자는 제품의 구매를 확정 하기 전에 아이템을 수정하거나 변경할 수 있고, 


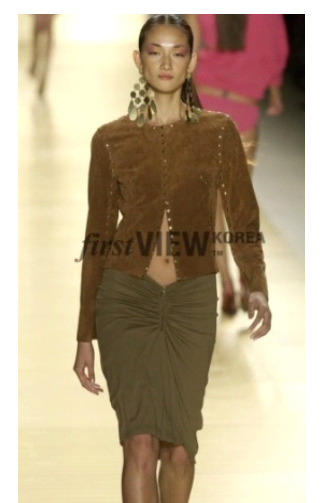

〈Fig. 4〉 Celline, $2003 \mathrm{~S} / \mathrm{S}$ From www.firstviewkorea.com

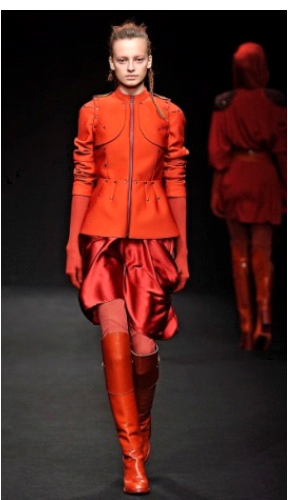

〈Fig. 5〉 A.F. Vandevorst, 2010 F/W From www.sam sungdesign.net

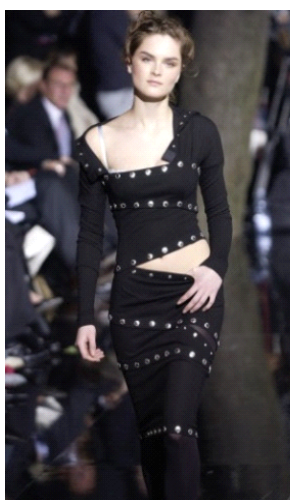

〈Fig. 6〉 D \& G, 2003 F/W From www.firstview korea.com

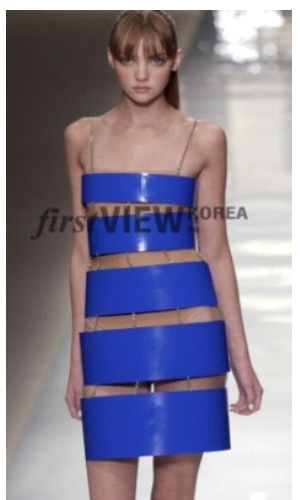

〈Fig. 7〉 Paco Rabanne, 2004 S/S, From www. firstviewkorea.com

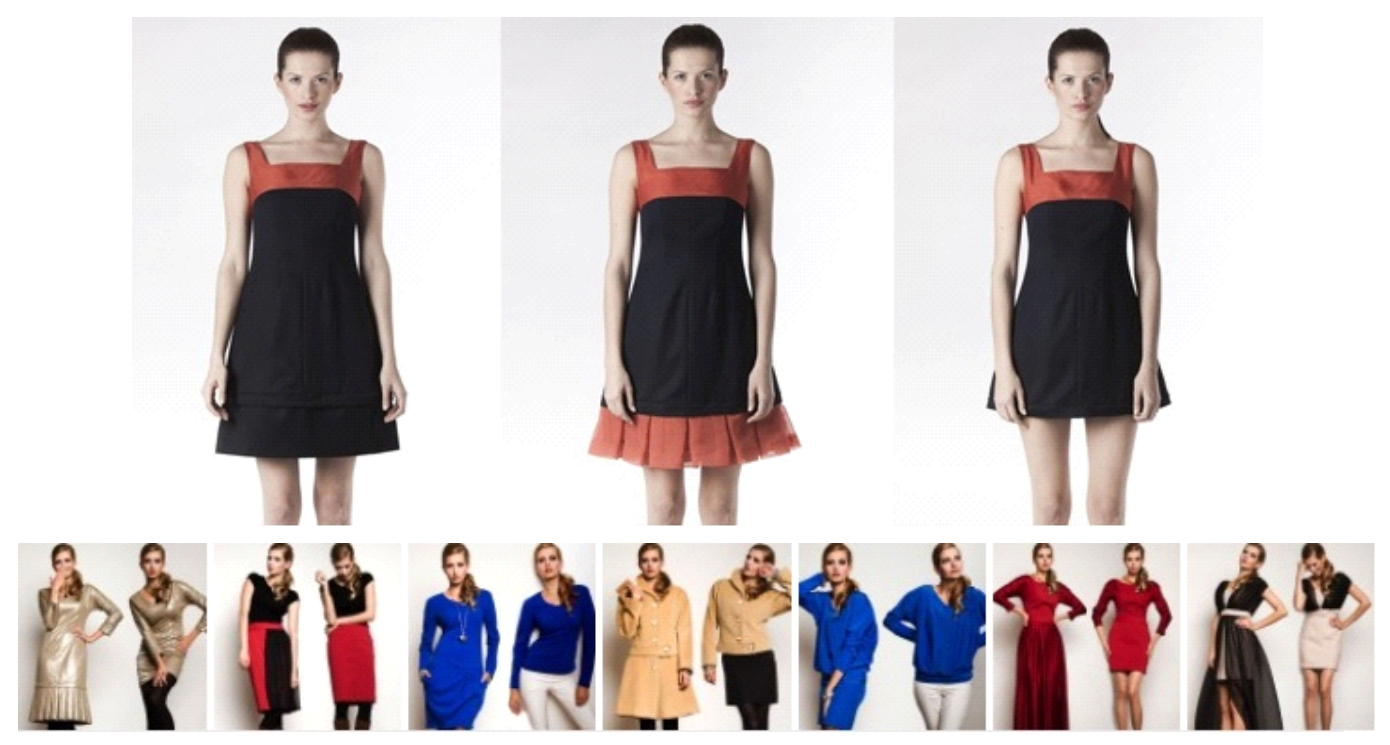

〈Fig. 8〉 Michael Hekmat. BLESSUS, 2011 S/S From http://magnifeco.com

모듈화된 다양한 디자인의 디테일 부분들을 선택 적으로 주문할 수 있다.

제품 분야의 모듈러 시스템에 포함된 조립구조 에서는 음각부와 양각부를 끼워 맞춰 연결하고, 필 요에 따라 부분이나 전체를 분해하는 방식이 특징 적으로 나타났었는데, 패션에서도 이러한 방식이 펠트나 가죽 소재를 이용하여 활용되고 있다. 별도 의 시접이 필요 없는 원단의 특성이 패스너를 이용 한 탈부착 방식보다 끼워 넣는 방식의 조립구조를
활용하는데 유리하기 때문이다. 2 차원의 평면적인 소재의 모듈들의 연결로 인해 3 차원의 구조물로 완 성하고, 이것을 착용하는 경우도 모듈러 시스템의 조립구조로 나타났다.

허은석(Eunsuk Hur)은 모듈러 패턴과 형태를 창 조하는 데에 있어서 패션 디자인에서의 실용적인 적 용을 위해 대칭, 모자이크 세공(tessellations), 프랙탈 기하학(fractal geometry)의 개념을 탐구해왔다. 주 로 레이저 커팅(Laser-cutting)을 이용해 펠트나 가 

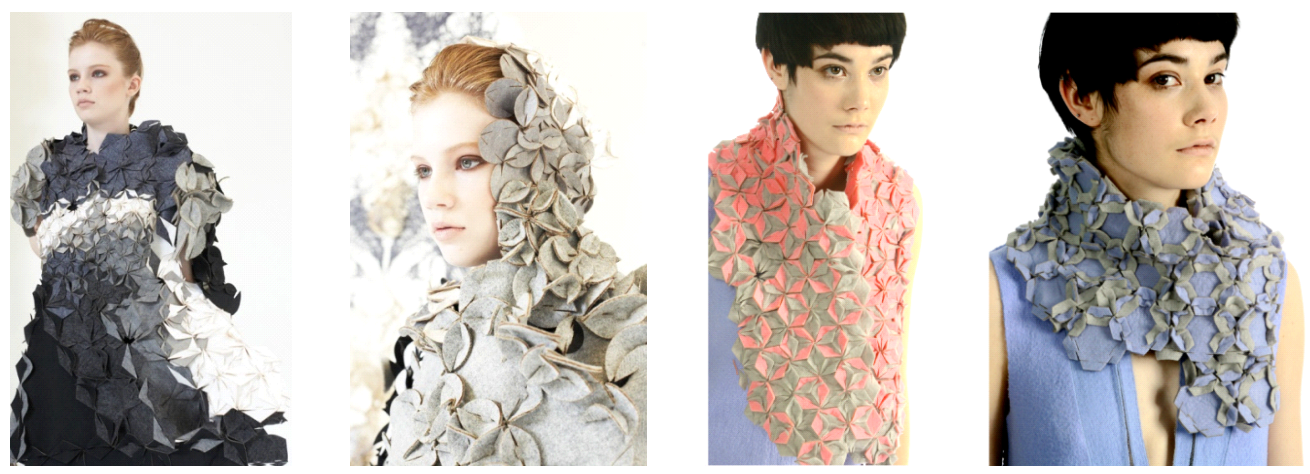

〈Fig. 9〉 Nomadic Wonderland, 2009 F/W From www.eunsukhur.com

죽으로 모듈러 조각들을 만들고, 자연적인 모티브 형태를 띠고 있는 조각들의 유기적인 모양으로 형 성된 연결구조를 이용해 모듈들을 서로 연결시켰 다. 'Nomadic Wonderland'의 작품들은 착용자의 의 지에 따라 결합되거나 분리될 수 있고, 이러한 모듈 러 조각들은 최종 사용자로 하여금 텍스타일(textile) 제품의 변형이나 창조에 유연하게 접근하여 디자 인 프로세스에 참여하도록 해준다(Fig. 9). 사용자 의 의지에 따라 결합하거나 분해할 수 있는 연동 조각들의 개발에 의해 결과물을 얻고 있는 것이다.

\section{Overlapping structure}

사전적 의미의 중첩(overlapping)은 '거듭 겹치거 나 포개어짐', ‘여러 층이 겹쳐 있는 형태'를 뜻하 며, 축적(accumulation)은 '지식, 경험, 자금 따위를 모아서 쌓음, 또는 모아서 쌓은 것'을 뜻하는데 (National Institute of the Korean Language, 2014), 본 연구에서는 겹치는 부분이 존재하면서 수직적으로 축적되는 구조를 모듈러 시스템에서의 중첩구조라 고 정의하고자 한다.

건축이나 제품에서의 중첩구조는 수직으로 겹쳐 쌓아 둘 수 있는 구조로 보관상의 공간 점유율을 낮출 수 있고, 공간 이동시 편리하며, 축적 방식에 따라 다양한 형태로 변형이 가능하다. 패션의 경우, 축적과 중첩구조는 주로 입체적인 볼륨감의 변화 를 주거나, 새로운 형태를 구축하고, 소재와 디테일 의 표현 도구로 활용되었다. 중첩구조는 단순한 형 태들을 겹쳐서 쌓아 올린 방식으로 사각형의 원단 에 주름을 넣어 겹친 티어드 스커트(tiered skirt)의
실루엣이 가장 많이 나타났다. 사례 분석을 통해 살펴본 모듈러 시스템 디자인에서의 중첩은 주로 의복 자체를 모듈로 보고 중첩시키는 경우, 의복 구성요소를 모듈로 보는 경우, 소재의 표면 재료들 을 모듈화하여 중첩시키는 경우로 크게 구분되어 나타났다.

의복 구성요소를 모듈로 보는 경우의 사례들은 구성요소 자체를 모듈로 보고, 요소들을 크기의 변 화를 주며, 반복적이고 규칙적으로 중첩시키거나, 칼라, 소매, 몸판 등의 구성요소들을 불규칙하게 겹 쳐 쌓아 배치하는 경우와 의복의 어느 한 부분의 디테일만을 강조하여 중첩시키는 경우 등으로 다 양하게 나타났다. 빅토르 앤 롤프(Victor \& Rolf)는 2010년 S/S의 작품에서는 중첩의 효과를 통해 비정 형적이고 비균형적으로 발달된 칼라, 소매와 네크 라인 실루엣들을 선보였다. 소매 형태와 스커트의 햄라인은 반원의 형태로 구성하였고, 원 형태의 크 기를 달리하며, 점진적인 변화를 주며, 중첩시켜 인 체의 형태를 과장하여 표현하였다(Fig. 10). 그리고 디테일의 크기를 규칙적으로 점증시키는 형태와 달리, 서로 다른 형태와 크기를 가진 부분들을 중 첩시켜 표현하기도 하였다.

영국의 아트 디렉터이자 레이디 가가(Lady Gaga) 의 의상 디자이너로도 유명한 페트라 토스(Petra Storrs) 가 발표한 $2009 \mathrm{~S} / \mathrm{S}$ 의 작품은 어깨에 동일한 유닛 들을 반복적으로 얹어 올리면서 실루엣을 과장시 켜 강조하고 있는데, 이를 통해 하키나 풋볼을 연 상시키는 보호 룩을 연출하였다(Fig. 11). 어깨에 활용된 모듈들은 바디 라인을 따라 유기적으로 재 
구성된 커팅으로 제작하여 점차적으로 확대되는 사이즈로 리듬감을 주고 있다.

일반적으로 의복을 구성하는 전형적인 소매, 몸 판, 칼라 등의 구조와는 상관없이 단순한 도형 형 태들의 조합만으로도 인체에 입힐 수 있는 3 차원 의 구조물이 가능하다는 것을 산드라 백룬드(Sandra Backlund)는 $2009 \mathrm{~S} / \mathrm{S}$ 의 작품들을 통해 보여주었 다. 사각형의 모듈들은 스펀지와 같은 보조물이 삽 입되어 형성된 직육면체 자체만으로도 볼륨감을 갖고 있으면서 수직적으로 축적되어 마치 인체 위 에 건축물들이 지어지고 집합해 있는 도시를 연상 시키도록 하는 효과를 얻었다(Fig. 12).

소재의 표면 재료로서의 모듈들이 중첩되어 재 질감에 입체감과 유동성을 주는 경우에는 모듈화 된 소재의 재료들을 중첩시킴으로써 풍성한 실루 엣을 표현하기도 하는데, 이상봉(Lie Sang Bong)은 $2008 \mathrm{~S} / \mathrm{S}$ 파리 컬렉션에서 가볍고 투명한 오간자를 원형의 동일한 모티브로 레이저 커팅하고 테두리 에 컬러의 그라데이션을 주어 유닛들을 제작하였 다(Fig. 13). 얇은 소재의 유닛들은 셀 수 없이 많은 수의 층으로 겹쳐져서 작품으로 탄생하였는데, 모 듈들을 연결할 때 자유로운 움직임이 가능하도록 일부분만을 고정하여 착용자가 움직이는 방향과 동작에 따라 마치 살아 움직이는 듯한 느낌을 주었 다. 이상봉의 작품에서 나타나는 모듈들의 조합은 키네틱 아트의 역동성이 묻어나는 것들이다. 따라 서 모듈러 시스템을 활용한 디자인은 유동적인 특 성들을 표현하기에 적합한 구조적인 특징이 있음

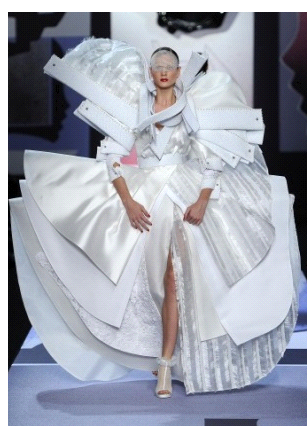

$\langle$ Fig. 10〉 Victor \& Rolf 2011 S/S, From www.sam sungdesign.net

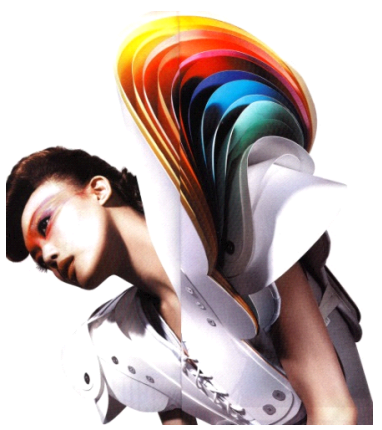

〈Fig. 11〉 Piece by Petra Storrs, 2009 S/S From http://petrastorrs.com
을 확인할 수 있었다.

\section{Arrangement structure}

배열이란 '일정한 차례나 간격에 따라 벌여 놓 음'을 의미하는 용어(National Institute of the Korean Language, 2014)로, 패션 분야의 모듈러 시스템은 건축, 제품에서와 마찬가지로 배열구조가 가장 단 순한 구조로 나타나며, 동일하거나 유사한 모듈들 의 일차원적인 나열과 재배열로 표현되었다. 모듈 러 시스템의 배열구조가 중첩구조와 다른 점은 모 듈들이 수평적이고 평면적으로 놓인다는 것이다. 현 대 패션에 표현된 배열구조는 패치워크(patchwork) 기법과 장식요소들의 배열과 의복 구성요소들의 배 열로 크게 나누어 볼 수 있었다. 단순한 기하학적 도형을 모듈로 이용한 장식요소들을 배열하는 경 우가 가장 많이 나타났으며, 의복의 구성요소들이 라고 할 수 있는 몸판, 소매, 카라, 주머니, 후드 등 을 하나의 구성단위 모듈로 보고, 이러한 유닛들의 해체와 재배열을 하는 사례들이 있었다.

모듈러 시스템에서는 기하학적이고 직선적인 모 듈들을 주로 사용하고 있었다. 존 리베(John Ribbe) 는 $2004 \mathrm{~F} / \mathrm{W}$ 컬렉션에서 패딩 모듈을 이용했는데, 사각형의 모티브들은 몸판과 모듈에 붙인 벨크로 때문에 탈, 부착이 가능하였고, 모듈들의 위치를 자 유롭게 배열하는 것도 가능하였다. 모듈들의 재배 열을 통해 새로운 형태를 창조하는 대표적인 사례 라고 하겠다(Fig. 14). 모듈이 된 모티브들을 강조 하기 위해 전체적인 실루엣은 절제되고, 컬러는 강

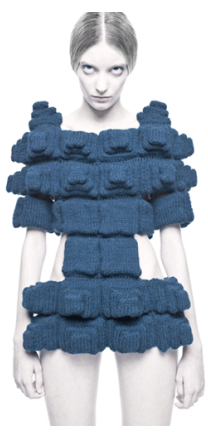

〈Fig. 12〉 Sandra

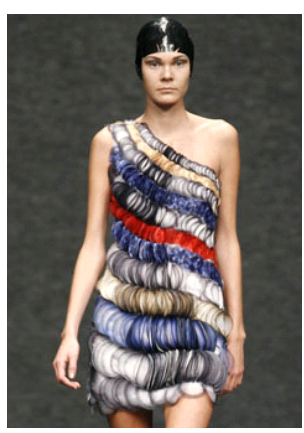

〈Fig. 13〉 Lie Sang Bong
Backlund, 2009 S/S. From 2008 S/S. From www. www.sandrabacklund.com samsungdesign.net 
조되었다.

핸드 니트의 크로쉐(crochet)는 개별적인 모티브 를 짤 수 있는 기법으로 독립적인 각각의 모티브들 을 연결하면서 배열에 따라 다양한 디자인을 가능 하게 한다. 다양한 형태의 모티브들은 개별적으로 일상에서 코스터(coaster)로 쓰일 뿐만 아니라, 서로 연결되어 패브릭의 형태로 실내 인테리어에 장식 용으로도 쓰이기도 하며, 편성물로 의상에서도 여 러 가지 아이템으로 활용되고 있다. 화려한 색채와 배색의 조화로 이루어진 패셔너블한 니트 작품을 선보이고 있는 브랜드인 미쏘니(Missoni)는 2010 $\mathrm{F} / \mathrm{W}$ 컬렉션에서도 이러한 크로쉐 모티브를 모듈로 이용해 서로 다른 형태와 크기를 연결한 작품들을 제작했다(Fig. 15). 크로쉐의 모티브들은 하나의 모 듈로서 독립적이면서도 조합에 의해 다양한 결과 물을 얻어낼 수 있는 패션의 모듈러 시스템의 유용 한 사례라고 할 수 있다.

의복 구성요소나 의복의 장식요소들이라고 할 수 있는 스팽클, 큐빅, 비즈 등의 단위 장식물 모듈의 배열을 통해 표면의 독특함을 디자인하는 경우 또 는 메탈이나 유리, 조개 껍질 등과 같은 다양한 이 질적인 재질을 모듈로 사용하여 부착한 사례들도 나타났다. 작은 조각들이 모여 다중적으로 비춰지 는 큐비즘의 요소와 유연한 곡선 라인이 만나 빛을 받으면 발광하는 형태를 구성하였다. 토드 린(Todd Lynn)은 $2011 \mathrm{~S} / \mathrm{S}$ 컬렉션에서 뱀의 허물벗기에서 영감을 받아 이를 의상으로 표현하였는데, 그 과정

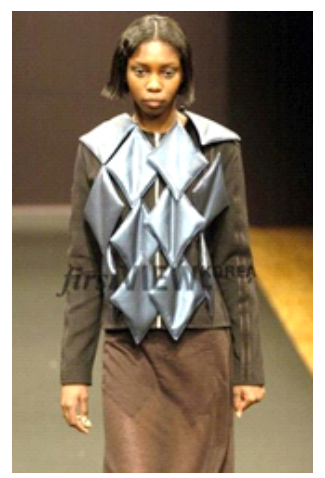

〈Fig. 14〉 John Ribbe, 2004 F/W From www. firstviewkorea.com

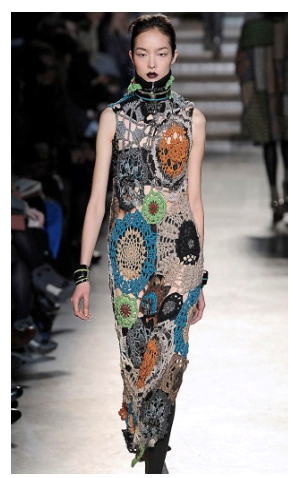

〈Fig. 15〉 Missoni, 2010 F/W. From www.samsung design.net

에서 입체적으로 휘어진 금속 조각들을 의상에 부 착했다(Fig. 16). 미니멀하고 현대적인 느낌을 주는 이 조각의 모듈들은 의상에서 가장 중요한 포인트 로 작용하였다.

레이 가와쿠보(Rei Kawakubo)는 다른 옷의 소매 형태들만을 모아서 스커트, 원피스, 재킷 등의 또 다른 아이템으로 새롭게 재구성하였다(Fig. 17). 의 복의 구성요소인 소매를 하나의 독립된 모듈로 보 고, 그것들만의 새로운 배열과 조합을 통해 통념을 깨는 의상들을 탄생시킨 것이다. $2010 \mathrm{~S} / \mathrm{S}$ 컬렉션 에 등장한 의상들은 소매와 어깨 패드로만 만들어 진 작품들이라고 해도 과언이 아니었다. 소매는 모 듈이 되고, 이 모듈들이 어디에 어떻게 콜라쥬(collage) 되느냐에 따라 의복은 새로운 형상을 갖추었다. 어 깨 패드의 돌출된 부분은 특히 풍만한 입체적인 실 루엣을 만들었는데, 정형화되고 딱딱한 아이템을 자유로운 실루엣으로 재해석한 것이었다.

\section{Inserting structure}

삽입은 '틈이나 구멍 사이에 다른 물체를 끼워 넣 음'을 의미(National Institute of the Korean Language, 2014)하는데, 패션 디자인의 모듈러 시스템에서는 의복의 전체 혹은 일부분을 넣거나 빼는 삽입과 교 환이 가능한 구조를 말한다. 이 구조는 넣기와 빼 기, 그리고 교환이 가능하므로 변화의 가능성을 동 반한다는 특성이 있다. 패션 디자인의 사례 분석 결과, 삽입이 되는 모듈의 형태는 제품이나 건축에

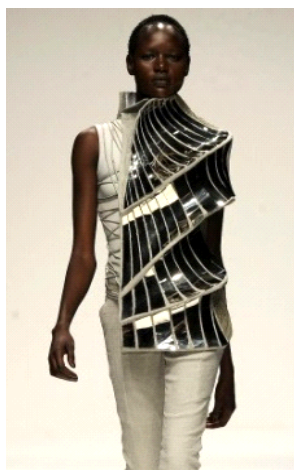

〈Fig. 16〉 Todd Lynn, 2011 S/S. From www. samsungdesign.net

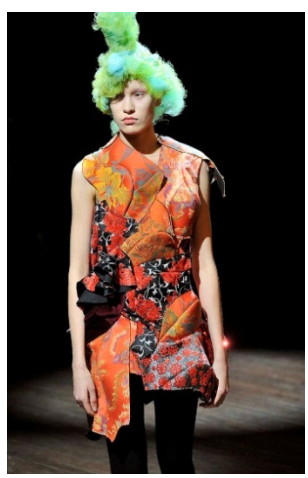

〈Fig. 17〉 Comme des Garcons, 2010 S/S. From www.samsungdesign.net 
서처럼 규격화되지는 않았으며, 의복의 일부분이나 장식적 요소들이 삽입구조로 나타났다. 패션에 표 현된 삽입구조는 크게 의복의 장식요소들이 모듈 이 되어 삽입되는 구조와 의복의 구성요소 일부가 모듈이 되어 서로 다른 의복에 삽입될 수 있는 구 조, 그리고 의복 아이템 자체가 모듈이 되어 다른 아이템에 삽입되는 구조로 나누어졌다.

장식 부자재로 쓰이는 일반적인 소재들 이외에 도 디자이너들의 독창적인 아이디어들이 돋보이는 삽입구조들도 나타났다. 반데버스트(A. F. Vandevorst) 의 $2010 \mathrm{~F} / \mathrm{W}$ 작품에서는 칠판 프린트를 한 셔츠에 규칙적으로 실제 쵸크(chalk)를 삽입해서 보는 사람 들의 흥미를 불러 일으켰다(Fig. 18). 이와 같은 독 창적인 장식 구조물의 활용은 이세이 미야케(Issey Miyake)의 $2012 \mathrm{~F} / \mathrm{W}$ 작품에서도 나타났는데, 다양 한 시도에서 출발한 이세이 미야케의 철학에 기반 한 새로운 시도가 계속되고 있음을 보여주었다. 이 세이 미야케는 망사 조직의 니트를 주머니처럼 공 간 구획하여 나누고, 그 안에 솜을 넣은 사각형의 구조물을 삽입하여 심플하면서도 강한 인상을 주 었다(Fig. 19). 사각형의 구조물들은 여러 의상에서 컬러를 달리하여 삽입되어 특유의 실루엣을 보여 주었고, 다양한 아이템에서 적용되었다.

의복의 구성요소 일부가 모듈이 되어 서로 다른 의복에 삽입될 수 있는 구조의 대표적인 사례는 마 르지엘라의 $2012 \mathrm{~F} / \mathrm{W}$ 와 $2014 \mathrm{~S} / \mathrm{S}$ 컬렉션에서 대표 적으로 나타났다. 그녀는 위의 배열구조 사례에서 살펴보았던 레이 가와쿠보의 모듈화된 소매와는 다
른 방식으로 의복 구성요소 중 소매를 모듈화 하였 는데, 몸판을 공유하고 소매를 교체하여 조합해 가 면 다양한 디자인이 나올 수 있도록 시도하였다(Fig. 20). 동일한 실루엣의 소매를 다양한 소재로 제작 하고 독립적으로 삽입과 교환을 할 수 있으며, 패 스너인 스냅이나 끈을 이용하여 손쉽게 연결하여 교체할 수 있다. 이 시즌 컬렉션에서 선보인 소매 의 자유로운 연결이 가능한 10 개의 작품 시리즈는 모두 서로 다른 의상과 소매를 교체하여 삽입한다 고 해도 무방하도록 모듈화되어 있으며, 연결과 분 리, 삽입과 교체를 통해서 다양한 디자인으로 바꿔 서 연출이 가능하다.

래그 앤 본(Rag \& Bone)의 $2010 \mathrm{~F} / \mathrm{W}$ 컬렉션의 작품은 아이폰, 블랙베리, 신용 카드 등 착용자가 필요에 따라 여러 가지 용품을 담을 수 있는 적당 한 크기의 미니 파우치들을 벨트에 걸었다(Fig. 21). 주머니는 본래 의복의 일부분으로 몸판에 고정적 으로 부착되어 있거나, 절개 라인의 일부분을 이용 한 솔기 주머니처럼 의복의 안쪽에 달려 있기 마련 이지만, 여기서 주머니는 벨트에 여러 개를 걸어 의 복의 일부분이 되면서도 필요에 따라 넣고 뺄 수 있는 모듈로서 역할을 한다. 컬러와 사이즈가 다양 한 주머니를 모듈화 한다면 의상의 종류와 컬러에 적합한 주머니들을 선택적으로 삽입하거나 교체할 수 있다.

\section{Folding structure}

'건축에서의 폴딩(Folding)은 다양한 형태 조직
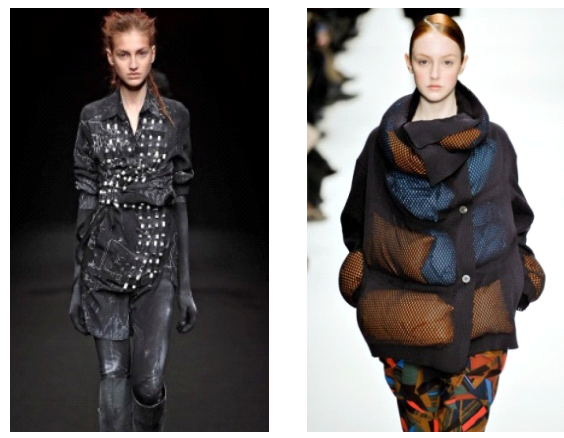

〈Fig. 18〉 AF Vandevorst, 〈Fig. 19〉 Issey Miyake, 2010 F/W From www. samsungdesign.net samsungdesign.net

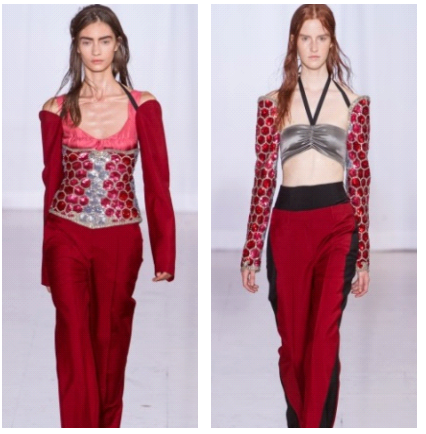

〈Fig. 20〉 Masion Martin Margiela, 2014 S/S From www.samsungdesign.net

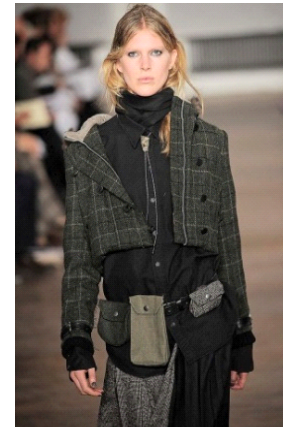

〈Fig. 21〉 Rag \& Bone, 2010 F/W From www. samsungdesign.net 
과 이것들의 다양한 기능적, 형태적인 잠재적 가능 성을 변화의 힘과 연결시켜 움직임에 의한 연속적 인 새로운 공간으로 구성하는 유용한 방법이다. 복 식에서 폴딩은 의복의 길이나 둘레 등의 사이즈를 조절하거나, 의복의 일부를 접어 내부에 숨겼다가 펼치는 과정에 의해 변형을 이루는 유형이다(Park, 2008). 건축과 제품에서의 접이구조는 각 부분이 연결되어 있는 형태로, 단순한 조작만으로 구조의 부피를 변화시킬 수 있으며, 부피의 축소로 인해 운반과 보관이 용이하다는 특징이 있다. 의복의 경 우에서도 가변적인 요소를 이용하여 부피의 변화 를 줄 수 있어, 특별한 패스너의 조작 없이 확대와 축소만으로 착용이 가능하며, 사이즈 조절이 가능 하다. 결합 방법과 방향, 크기 등의 변화로 인해 다 양한 작품으로의 변형이 가능하다. 패션에 나타난 모듈러 시스템의 사례 분석에서도 접이구조는 착 용자의 상황과 목적에 따라 모듈화된 유닛을 펼치 고 접어 넣어, 형태의 축소와 확대가 가능한 것으 로 나타났다. 접이구조에서 가장 많이 나타난 사례 는 일본의 전통적인 종이 접기 테크닉인 '오리가 미'의 적용 방식이었고, 그에 따라 많은 디자이너 들이 의상의 재료로 종이를 이용하기도 하였다. 기 하학적 도형의 형태를 규칙적이고 독립적으로 평 면 배치한 접이구조가 나타났으며, 그 외에는 다른 구조 방식들과 마찬가지로 의복의 일부분을 균일 하게 나누어 모듈화하거나, 의복의 구성요소를 하 나의 모듈로 간주했을 때 그 모듈이 되는 소매나 몸판 등을 접는 방식에 의해 나타났다.

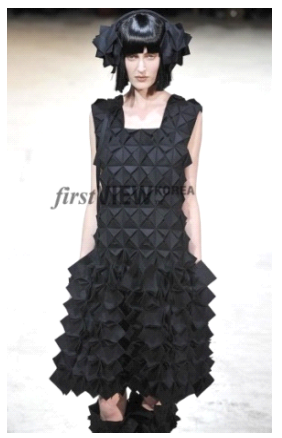

〈Fig. 22〉 Yohji Yamamoto 2013 F/W, From www. firstviewkorea.com

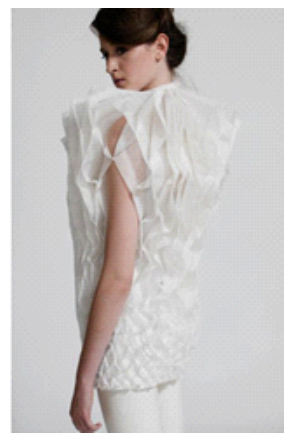

〈Fig. 23〉Alba Prat, 2011 S/S. From http://albaprat.com

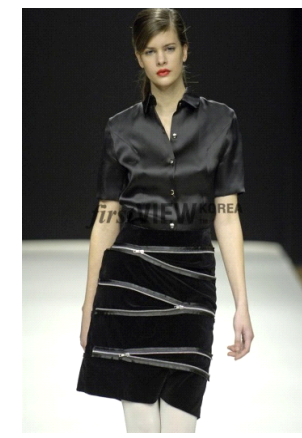

〈Fig. 24〉 John Ribbe 2007 F/W From www. firstviewkorea.com
제작 방식에 따라 구분하자면, 오리가미는 기본 적으로는 연결된 한 장의 종이로 작업을 하지만, 다 양한 조형 효과를 위해 컷을 넣어 연결하는 방법과 무수히 많은 유닛을 작업하여 합하는 방법도 있다 (Choi, 2009). 한 장의 종이를 이용하여 접힘이나 구 김만으로 형태를 변형하는 경우나, 완전히 절단하 지 않고 컷을 넣고 연결하는 방식과 달리, 유닛형 은 각각의 완성된 파트를 조합하는 방식이다. 요지 야마모토(Yohji Yamamoto)의 2013 F/W 컬렉션 컨 셉은 80 년대의 불필요한 장식을 제외한 블랙 룩을 기반으로 했지만, 그는 여기에 복잡한 커팅을 더했 다(Fig. 22). 삼각형과 사각형의 반복적인 접이구조 를 가지고 있는 유닛을 제작하여 봉제의 과정으로 연결한 의상들을 구성했으며, 한 치의 오차 없이 정확한 오리가미 드레스의 다양한 실루엣 탐구가 이어졌다. 오리가미의 형태는 구성 원리에 따라서 도 분류가 가능하며, 선의 배열에 의한 괘선원리, 등변 혹은 이등변 배열에 의한 삼각원리, 임의의 주름선과 불규칙 면에 의한 구김원리가 있다(Choi, 2009). 알바 프랫(Alba Prat)의 오리가미 형식을 이 용한 기하학적인 드레스는 직선의 배열을 이용한 괘선의 원리와 삼각원리가 모두 조합된 디자인으 로서 원단의 면과 면을 연결하는 방식에 의해 생긴 마름모꼴의 공간들의 접힘에 의해 유동적인 실루 엣을 형성한다(Fig. 23).

패션에 나타난 모듈러 시스템의 접이구조는 오 리가미 방식이 가장 많이 나타났지만, 그 외에도 거 의 균등한 비율로 세분화한 모듈들의 접힘을 이용 
한 사례들이 확인되었다. 존 리베(John Ribbe)는 특 히 접어 넣기에 의해 복식의 가변성을 표현하는 디 자이너로 $2007 \mathrm{~F} / \mathrm{W}$ 작품처럼 패스너를 이용해 의 복의 일부분의 내부에 접어 넣기를 할 수 있는 공 간을 확보하고 패스너를 오픈했을 때 접혀 있던 옷 의 일부분을 꺼내어 길이의 확장이나 부피의 확장 을 시도했다. 그 중에서도〈Fig. 24〉는 스커트를 수 직방향으로 일정한 비율로 나누어 모듈화하고, 접 이구조를 활용했는데, 지퍼가 오픈되는 정도에 따 라 펼쳐지는 분량의 정도의 차이도 생기면서 다양 한 길이와 실루엣이 가능한 디자인이다. 이상봉(Lie Sang bong)이 $2008 \mathrm{~F} / \mathrm{W}$ 시즌에 발표한 가방은 원 반 형태의 모듈들이 서로 아코디언 주름 형태의 접 이구조로 연결되어 부피의 자유로운 확장과 축소 가 가능하다(Fig. 25).

지금까지 패션에서 표현된 모듈러 시스템의 구 조 방식을 조립구조, 중첩구조, 배열구조, 삽입구 조, 접이구조의 5 가지로 분류하여 분석하였으며, 〈Table 2〉에서 건축과 제품에서 나타난 구조 방식 과 달리 패션에 표현된 모듈러 시스템의 구조 방식 에서 나타나는 특징들을 정리하였다.

\section{Conclusion}

본 연구는 모듈이 조합되어 완성되는 형태를 통 해서 기능의 확장, 호환성을 확보할 수 있으며, 사 용자의 다양한 욕구에 맞추어 활용도가 증가하고 있는 모듈러 시스템에 관하여 고찰하고, 그 활용 방 안을 조사하여 구조 방식을 분류하였다. 기본 모듈 의 근본적인 차별화와 조합으로 다양한 표현이 가
능하게 할 수 있는 유연한 표현 방법의 개발을 위 한 시각적 자료를 제공하고자 패션에서 표현된 모 듈러 시스템의 구조 방식을 분석하였으며, 연구의 결과는 다음과 같다.

첫째, 패션에 나타난 모듈러 시스템의 분석을 위 한 기준 마련을 위해 모듈러 디자인 관련 이론과 선행 연구 그리고 건축과 제품에 나타난 모듈러 시 스템의 사례 분석을 통해 분석한 구조 방식 중 공 통적으로 나타나는 구조는 조립구조, 중첩구조, 배 열구조, 삽입구조, 접이구조의 5가지로 도출되었다.

둘째, 현대 패션에 나타나고 있는 모듈러 시스템 의 구조 방식을 분석한 결과, 중첩구조 $(34 \%)$ 가 가장 많이 나타났으며, 배열구조 $(30.4 \%)$, 조립구조 $(20.3 \%)$, 접이구조 $(8 \%)$, 삽입구조 $(7.3 \%)$ 순의 출현 빈도를 보 였다.

셋째, 건축, 제품과는 달리 패션에서의 조립구조 는 탈, 부착 방식을 위한 패스너의 활용이 중요하 고, 중첩구조는 수직적 축적에 의한 입체적인 볼륨 감의 표현이 주로 나타났다. 배열구조는 중첩구조 에 비해 모듈의 단순한 나열에 의한 수평적이고 평 면적인 형태를 나타냈으며, 삽입구조는 규격화되지 않은 모듈들이 의복의 일부분이나 장식적 요소로 활용되었다. 접이구조는 주로 축소와 확대가 가능 한 오리가미 기법을 활용한 사례로 나타났다. 대부 분의 구조 방식에서 의복 구성 요소를 모듈로 보는 경우, 의복의 일부분을 균일하게 나누어 모듈화 하 는 경우와 의복의 장식 요소를 모듈화하여 디자인 하는 경우들로 구분되어 표현되었다.

모듈러 시스템에 대한 이론의 정립과 실제 활용 사례 분석을 통해 도출한 결과는 모듈러 시스템 디

$\langle$ Table 2〉 The characteristics of modular system in fashion design

\begin{tabular}{c|l}
\hline \multicolumn{1}{c|}{ Structural method } & \multicolumn{1}{c}{ The characteristics of modular system in fashion design } \\
\hline Assembling structure & Utilizing fastener, modifiable structure, assembling independent components of costume \\
\hline Overlapping structure & $\begin{array}{l}\text { Utilizing for 3D volume variation or construction of new form, layering items of costume or } \\
\text { components of costume, modularity of surface materials }\end{array}$ \\
\hline Arrangement structure & $\begin{array}{l}\text { Horizontal and flat arrangement of same or similar unit, patchwork / arranging components of } \\
\text { costume / arranging ornamental components, mainly used simple geometric figures }\end{array}$ \\
\hline Inserting structure & Accompany variability, inserting part of costume or ornamental components \\
\hline Folding structure & $\begin{array}{l}\text { Mainly used origami technique, folding and unfolding units enabled reduction and expansion of } \\
\text { costume }\end{array}$ \\
\hline
\end{tabular}


자인 개발의 기초가 될 것이며, 다양한 적용 방안 을 모색하는 데에 있어 지침이 될 것으로 사료된다.

\section{References}

Ahn, H. J.(2005). A study of jewelry design using modular system. Unpublished master's thesis, Hanyang University, Seoul, Korea.

Alvisse, M.(2009). http://www.trendhunter.com. February 5, 2014, from http://www.trendhunter.com/trends/ puzzling-transformer-furniture-michael-alvisse-be d-sofa-chair-stop-playing-

Backlund, S.(2009). http://www.sandrabacklund.com Retrieved January 4, 2014, from http://www.sandra backlund.com/previous-collection.php?page $=39$

Bae, J. H.(2005). A study on the development of "multi furniture design": focused on the modular system. Unpublished master's thesis, Hanyang University, Seoul, Korea.

Celine(2003). http://www.firstviewkorea.com. Retrieved January 17, 2014, from http://www.firstviewkorea. com/Collection/PhotoImageViewPop.aspx?Season= SS005\&City $=$ CD001\&Event $=$ EV001\&Designer $=$ $437 \&$ Cate $=\mathrm{CC} 001$

D \& G(2003). http://www.firstviewkorea.com. Retrieved February 12, 2014, from http://www.firstviewkorea. com/Collection/PhotoImageViewPop.aspx?Seaso $\mathrm{n}=\mathrm{SS} 006 \&$ City $=\mathrm{CD} 002 \&$ Event $=$ EV001\&Design er $=88 \&$ timeLinePageNo $=1$

Garcons, C. D.(2010). http://www.samsungdesign.net. Retrieved February 21, 2014, from http://www. samsungdesign.net/Collection/ForWomen/rDesig nerListImage. asp? $a n=31 \&$ ItemIdx $=208 \&$ Item $=\mathrm{Pa}$ ris\&year $1=2010 \&$ season $=$ ss $\&$ Designerid $x=4437$ $\&$ Designer $=\&$ rYear $=2010 \&$ rSeason $=$ ss $\&$ rItem $=\&$ $\mathrm{rSex}=$ Women $\& \mathrm{rDesigner}=\mathrm{Comme}+\mathrm{des}+\mathrm{Gar} \% 26$ ccedil\%3Bons

Go, Y. K. (2006). A study on the modular design of unit bath room system. Unpublished master's thesis, Hongik University, Seoul, Korea.

Hekmat, M.(2011), http://magnifeco.com. Retrieved
December 11, 2013, from http://magnifeco.com/ special-report-blessus-modular-clothing/women/

Hur, E. S.(2009). http://www.eunsukhur.com. Retrieved January 21, 2013, from http://www.eunsukhur.com/ \#/nomadic_wonderland/recent_project:_about_no rmadic_wonderland/normadic_wonderland

Jacobides, M.(1997). Unbundling, standardization and competitive dynamics. Strategic Management Society Conference, Barcelona, Spain.

Jeong, D. Y.(2008). Mass customization. Seoul: mplanning.

Ji, J. H.(2012). A study on the customized remodeling by modular method housing. Proceeding of Spring Annual Conference of KHA, 1, 2234-3571.

Kim, H. Y.(2011). A study on the development of mass customizing the modularized floral art \& design. Unpublished master's thesis, Sookmyung Women's University, Seoul, Korea.

Kim, J. H.(2012). A study on the practical application of modular construction for residental facilities. Unpublished master's thesis, Sunchon National University, Sunchon, Korea.

Kim, Y. K.(2006). A study on the modular systems in modern fashion. Journal of Korean Society of Design Culture, 12(1), 24-33.

Kurokawa, K.(1971). http://www.businessinsider.com. Retrieved December 6, 2013, from http://www. businessinsider.com/kisho-kurokawas-nakagin-ca psule-tower-2013-10?op=1

Kwon, Y. H.(2002). Introduction to architecture. Yeoungju: A publishing department of Dongyang University.

Lara, A., \& Nogueron, P.(2009). http://www.ecofriend. com. Retrieved December 21, 2013, from http:// www.ecofriend.com/eco-architecture-adex-a-solar -powered-prefabricated-module-based-living-unit. html

Lee, B. J., \& Kim, C. U.(2000). A general theory of architecture. Seoul: Kimoondang.

Lie, S. B.(2008). http://www.samsungdesign.net. Retrieved February 22, 2014, from http://www.samsungdesign. 
net/Collection/ForWomen/rDesignerListImage.asp? an $=24 \&$ ItemIdx $=135 \&$ Item $=$ Paris \&year $1=2008 \&$ season $=$ ss $\&$ Designerid $=2405 \&$ Designer $=\& r Y e a$ $\mathrm{r}=2008 \& \mathrm{rSeason}=\mathrm{Ss} \& \mathrm{rItem}=\& \mathrm{rSex}=$ Women $\& \mathrm{rD}$ esigner $=$ Lie + Sang + Bong

Lynn, G.(2008). http://www.ecofriend.com. Retrieved January 2, 2014, from http://www.ecofriend.com/ blobwall-modular-building-system-to-replace-bric k-and-mortar.html

Lynn, T.(2011). http://www.samsungdesign.net. Retrieved February 21, 2014, from http://www.samsungdesign. net/Collection/ForWomen/rDesignerListImage.asp? an=31\&ItemIdx=206\&Item $=$ London $\&$ year $1=201$ $0 \&$ season $=$ ss \&Designerid $\mathrm{x}=4211 \&$ Designer $=\& \mathrm{r}$ Year $=2010 \& r$ Season $=$ ss\&rItem $=\& r S e x=$ Women \&rDesigner $=$ Todd + Lynn

Magformers(2005). http://www.magformers.co.kr. Retrieved January 19, 2014, from http://www.magformers. co.kr/brand/feture.asp

Margiela, M.(2014). http://www.samsungdesign.net. Retrieved February 25, 2014, from http://www.sam sungdesign.net/Collection/ForWomen/rDesignerL istImage asp an $=63 \&$ ItemIdx $=380 \&$ Item $=$ Paris $\&$ year $1=2014 \&$ season $=$ ss $\&$ Designerid $x=11900 \& D$ esigner $=\&$ rYear $=2014 \&$ rSeason $=$ ss $\&$ rItem $=\&$ rSe $\mathrm{x}=$ Women\&rDesigner=Maison+Martin + Margiela

Mende, B.(2012). http://inhabitat.com. Retrieved December 22, 2013, from http://inhabitat.com/loop-amultifunctional-piece-of-furniture-that-can-be-a-c hair-chaise-bookshelf-or-table/boaz-mendel-multi functional-furniture-loop-2/

Missoni(2011). http://www.samsungdesign.net. Retrieved February 13, 2014, from http://www.samsungdesign. net/Collection/ForWomen/rDesignerListImage.asp? an=31\&ItemIdx=207\&Item=Milan\&year $1=2010$ $\&$ season $=$ ss $\&$ Designerid $=4293 \&$ Designer $=\& r Y$ ear $=2010 \&$ rSeason $=$ ss \&rItem $=\& r S e x=$ Women $\& r$ Designer=Missoni

Miyake, I.(2012). http://www.samsungdesign.net. Retrieved February 5, 2014, from http://www.samsungdesign.net/ Collection/ForWomen/rDesignerListImage.asp?a $\mathrm{n}=49 \&$ ItemIdx $=300 \&$ Item $=$ Paris\&year $1=2012 \& \mathrm{~s}$ eason $=\mathrm{fw} \&$ Designeridx $=8712 \&$ Designer $=\& \mathrm{rY}$ ear $=2012 \&$ rSeason $=$ fw\&rItem $=\& r S e x=$ Women $\& \mathrm{rD}$ esigner=Issey+Miyake

Molodrsign.(2003). http://www.samsungdesign.net. Retrieved January 21, 2014, from http://www.samsungdesign.net/ Fair/ExhibitionReport/content.asp?an=413\&keyw ord $=$ modular

Park, D. J.(2008). A study on the expansion module system of application for animal pictogram design. Unpublished master's thesis, Ewha Women's University, Seoul, Korea.

Park, S. S.(2008). A study on modifiable design in contemporary fashion. Unpublished master's thesis, Hongik University, Seoul, Korea.

Prat, A.(2011). http://albaprat.com. Retrieved February 4, 2014, from http://albaprat.com/\#!ss11-syntheticoceans

Rabanne, P.(2004). http://www.firstviewkorea.com. Retrieved December 13, 2013, from http://www. firstviewkorea.com/Collection/PhotoImageViewP op.aspx? Season $=\mathrm{SS} 007 \&$ City $=\mathrm{CD} 001 \&$ Event $=\mathrm{E}$ V001\&Designer $=484$

Rag \& Bone(2010). http://www.samsungdesign.net. Retrieved February 12, 2014, from http://www. samsungdesign.net/Collection/ForWomen/rDesig nerListImage. asp? an $=33 \&$ ItemIdx $=213 \&$ Item $=\mathrm{Ne}$ $\mathrm{w}+$ York\&year $1=2010 \&$ season $=$ fw $\&$ Designeridx $=$ 4754\&Designer $=\&$ Year $=2010 \&$ rSeason $=$ fw $\&$ rIt $\mathrm{em}=\& \mathrm{rSex}=$ Women $\& \mathrm{rDesigner}=\mathrm{Rag}+\% 26+$ Bone

Ribbe, J.(2004). http://www.firstviewkorea.com. Retrieved December 20, 2013, from http://www.firstviewkorea.com/ Collection/PhotoImageViewPop.aspx?Season=SS 008\&City $=$ CD001\&Event $=$ EV001\&Designer $=46$ $5 \&$ timeLinePage $\mathrm{No}=1$

Ribbe, J.(2007). http://www.firstviewkorea.com. Retrieved December 21, 2013, from http://www.firstviewkorea.com Collection/PhotoImageViewPop.aspx?Season=SS 014\&City $=$ CD001\&Event $=$ EV001\&Designer $=46$ $5 \&$ Cate $=\mathrm{CC} 001$

Salm, G., \& Salm, J.(2001). http://mioculture.com. Re- 
trieved January 21, 2014, from http://mioculture. com/create.html

Sanchez, R.(1995). Strategic flexibility in product competition. Strategic Management Journal, 16, 135 159.

Shigeru, B.(2000). http://detail-online.com. Retrieved January 11, 2014, from http://detail-online.com/ inspiration/house-near-tokyo-107660.html

Son, S. M.(2012). Air-containing multi-functional jacket design utilizing modular systems: Focused on cushioning, heat Insulation and portability. The Research Journal of the Costume Culture, 20(2), 222-237.

Storrs, P.(2009). http://petrastorrs.com. Retrieved January 17, 2014, from http://augustinewong.files.wordpress. com/2010/01/1.jpg

Thermaltake.(2011). http://www.thermaltake.com. Retrieved January 14, 2014, from http://www.thermaltake. com/products-model.aspx?id=C_00001542

Ulrich, K., \& Tung, K.(1991). Fundamental of product modularity. Proceedings of the 1991 ASME Winter Annual Meeting Symposium on Issues in Design/ Manufacturing Integration, Atlanta.

Vandevorst, A. F.(2010). http://www.samsungdesign. net. Retrieved December 16, 2013, from http:// www.samsungdesign.net/Collection/ForWomen/r DesignerListImage.asp?an=33\&ItemIdx=224\&Ite $\mathrm{m}=$ Paris\&year $1=2010 \&$ season $=\mathrm{fw} \&$ Designerid $\mathrm{x}=$ 5076\&Designer $=\&$ Year $=2010 \&$ rSeason $=$ fw $\&$ rIt em $=\& r S e x=$ Women $\&$ Designer $=\mathrm{A} \% 2 \mathrm{EF} \% 2 \mathrm{E}+\mathrm{V}$ andevorst

Victor \& Rolf(2011). http://www.samsungdesign.net. Retrieved December 22, 2013, from http://www. samsungdesign.net/Collection/ForWomen/rDesig nerListImage .asp? $\mathrm{an}=38 \&$ ItemIdx $=244 \&$ Item $=\mathrm{Pa}$ ris \&year $1=2011 \&$ season $=$ ss $\&$ Designeridx $=6118$ $\&$ Designer $=\&$ rYear $=2011 \&$ rSeason $=$ ss $\&$ rItem $=\&$ rSex $=$ Women\&rDesigner $=$ Viktor $+\% 26+$ Rolf

Yamamoto, Y.(2013). http://www.firstviewkorea.com. Retrieved December 16, 2013, from ttp://www. firstviewkorea.com/Collection/PhotoImageViewP op.aspx .Season $=\mathrm{SS} 028 \&$ City $=\mathrm{CD} 001 \&$ Event $=\mathrm{E}$ V001\&Designer $=293 \&$ Cate $=\mathrm{CC} 001$

Yang, H. Y.(2008). Modular system expressed in structural system of fashion since the late of 20C: Focusing on the fashion of Yeohlee Teng, John Ribbe, and Galya Rosenfeld. Journal of the Korean Society of Clothing and Textiles, 32(5), 788-799.

Yoo, J. C.(2009). Expression analysis of the modern fashion design used Origami's expression methods. Journal of the Korean Home Economics Association, 47(4), 1-10.

Yoon, J. Y.(2006). A study on adaptation potential of modular construction for temporary housing for refugees from disaster. Unpublished master's thesis, Yonsei University, Seoul, Korea. 